\title{
PENURUNAN SALINITAS (KADAR KLORIDA) ARTIFISIAL DENGAN PROSES PERTUKARAN ION (ION EXCHANGE)
}

\author{
Musyarrofah, M. Irfa'i, Abdul Khair \\ Poltekkes Kemenkes Banjarmasin Jurusan Kesehatan Lingkungan \\ Email : ofahsuhaidi27@gmail.com
}

\begin{abstract}
Decreasing Of Salinity (Chloride Condition) Artificially By Ion Exchange Process. Brackish water caused of high chloride sodium content, giving to feel briny at water. The only chemical process can remove chloride is the ion exchange. The aim of this study was to determine the difference of percentage decreasing of chloride levels in variations of chloride level in brackish water $(870 \mathrm{mg} / \mathrm{l}, 1712 \mathrm{mg} / \mathrm{l}, 2501 \mathrm{mg} / \mathrm{l}$ ) and variation of sampling time (1,5 hours, 3 hours, 4,5 hours). Brackish water used the result of dilution of brines using freshwater. This process brackish water by passing into a resin media tube's diameter $5 \mathrm{~cm}$ and $40 \mathrm{~cm}$ high with flow discharge $100 \mathrm{ml} / \mathrm{min}$. The results of chloride levels after the process still exceeded the quality standard Permenkes RI No.492/MENKES/PER/IV/2010. The avarage chloride levels after from the chloride 870 $\mathrm{mg} / \mathrm{l}$ is 776,7 mg/l, the chloride $1712 \mathrm{mg} / \mathrm{l}$ is $1520 \mathrm{mg} / \mathrm{l}$ and the chloride $2501 \mathrm{mg} / \mathrm{l}$ is 2139 $\mathrm{mg} / \mathrm{l}$. From Two-Way-Anova test showed a significant difference between the percentage of decreasing chloride levels in various sampling time, the variation of initial chloride level, and interaction between variation in initial chloride content and sampling time.
\end{abstract}

Keywords: Ion exchange, Synthetic resin, Chloride level

\begin{abstract}
Abstrak: Penurunan Salinitas (Kadar Klorida) Artifisial Dengan Proses Pertukaran Ion (Ion Exchange). Air payau disebabkan adanya kandungan Natrium Klorida (NaCl) yang tinggi, yang memberikan rasa asin pada air. Satu-satunya proses kimia yang dapat menghilangkan klorida dari air adalah pertukaran ion. Penelitian ini bertujuan untuk mengetahui perbedaan persentase penurunan kadar klorida artifisial pada variasi kadar klorida awal air payau ( $870 \mathrm{mg} / \mathrm{l}, 1712 \mathrm{mg} / \mathrm{l}, 2501 \mathrm{mg} / \mathrm{l}$ ) dan variasi waktu sampling (1,5 jam, 3 jam, 4,5 jam). Air payau yang digunakan hasil pengenceran air asin dengan air tawar. Proses ini dengan melewatkan air payau ke media resin diameter kolom $5 \mathrm{~cm}$ dan tinggi $40 \mathrm{~cm}$ dengan debit aliran $100 \mathrm{ml} /$ menit. Hasil pemeriksaan kadar klorida sesudah proses masih melebihi baku mutu Permenkes RI No.492/MENKES/PER/IV/2010. Rata-rata kadar klorida sesudah pada klorida awal $870 \mathrm{mg} / \mathrm{l}$ adalah 776,7 mg/l, pada $1712 \mathrm{mg} / \mathrm{l}$ adalah $1520 \mathrm{mg} / \mathrm{l}$ dan pada $2501 \mathrm{mg} / \mathrm{l}$ adalah $2139 \mathrm{mg} / \mathrm{l}$. Hasil uji statistik Two Way Anova menunjukkan adanya perbedaan persentase penurunan kadar klorida pada berbagai variasi waktu sampling, variasi kadar klorida awal, dan interaksi antara variasi kadar klorida awal dan waktu sampling.
\end{abstract}

Kata kunci; Pertukaran ion, Resin sintetis, Kadar klorida

\section{PENDAHULUAN}

Indonesia merupakan negara kepulauan terbesar di dunia yang memiliki panjang pantai lebih dari 80.000 $\mathrm{km}$. Sebagian besar penduduk Indonesia tinggal di daerah pesisir [1]. Wilayah pesisir pantai dan pulau-pulau kecil di tengah lautan lepas merupakan daerah yang miskin akan sumber air tawar sehingga timbul masalah yakni kurangnya pemenuhan kebutuhan air bersih. Sumber daya air yang terdapat di daerah tersebut umumnya berkualitas buruk, misalnya air tanah yang payau atau asin. Kualitas air tersebut karena mengandung kadar garam ataupun Total Dissolved Solid (TDS) yang sangat tinggi. Hal itu dikarenakan adanya intrusi air laut ke sumber air tawar [2]. Intrusi air laut pada dasarnya adalah proses masuknya air laut di bawah permukaan air tanah melalui akuifer di daratan atau di daerah pantai. Intrusi 
tersebut menyebabkan rasa asin yang berlebih pada air payau yang disebabkan adanya kandungan Natrium Klorida $(\mathrm{NaCl})$ yang tinggi. Klorida $(\mathrm{Cl})$ merupakan anion pembentuk $\mathrm{NaCl}$ yang menyebabkan rasa asin dalam air.

Untuk mengatasi permasalahan tersebut dibutuhkan teknologi pengolahan air yang sesuai dan tepat guna. Beberapa penelitian tentang penurunan kadar garam pada air asin telah dilakukan, diantaranya penelitian tentang destilasi air laut oleh Astawa, et al. (2011) yang menggunakan variasi plat penyerap tipe datar, plat penyerap tipe bergelombang dan plat penyerap tipe bergelombang yang dilapisi batu kerikil. Hasil pengujian menunjukkan penyerap radiasi tipe bergelombang yang dilapisi batu kerikil lebih banyak menghasilkan kondensat yaitu sebesar 1.295 gram dengan efisiensi rata-rata mencapai $12,33 \%$. Masalah yang biasa timbul pada sistem destilasi adalah kerak dan karat pada peralatan. Apabila terjadi kerak pada tube penukar panas evaporator maka efisiensi panas dan produksi air tawar akan berkurang [3].

Khairunnisa, et al. (2015) telah melakukan pengolahan air laut untuk menyisihkan ion klorida $\left(\mathrm{Cl}^{-}\right)$ menggunakan tanah lempung yang teraktivasi. Dari hasil penelitian didapatkan efisiensi penyisihan ion $\mathrm{Cl}^{-}$ berkisar antara 98,2\% - 95,7\%. Metode ini sangat efektif dilakukan tetapi harus memperhatikan kondisi dan kandungan tanah lempung [4]. Tanah lempung yang digunakan harus tidak mengandung zat berbahaya agar tidak bereaksi dengan zat lain dan tidak menghalangi proses dalam pertukaran ion.

Alternatif bahan lain dalam proses pertukaran ion adalah menggunakan resin penukar ion. Resin penukar ion pertama kali digunakan disebut zeolit. Zeolit atau resin adalah suatu senyawa radikal dari bahan penukar ion dapat ditulis $\mathrm{Na}_{2} \mathrm{Z}$ (sodium Zeolit) dan $\mathrm{Na}_{2} \mathrm{R}$

\section{BAHAN DAN CARA PENELITIAN}

Jenis penelitian yang digunakan dalam penelitian ini adalah eksperimen, dimana peneliti melakukan perlakuan terhadap (sodium Resin). Sodium zeolit adalah bahan mineral yang merupakan senyawa kompleks. Sekarang ini keberadaan zeolit hampir semuanya telah diganti dengan resin penukar ion sintetis yang banyak diproduksi dari bahan sintetis hidrokarbon dengan sebutan resin. Hal ini karena resin sintetis mempunyai kapasitas pertukaran ion yang lebih besar [5].

Apriani, et al. (2010) telah melakukan penelitian menggunakan resin sintetis untuk penurunan kandungan $\mathrm{Na}^{+}$dan $\mathrm{Cl}^{-}$. Dari hasil penelitian menunjukkan efisiensi penyisihan $\mathrm{Na}^{+}$91,35\% dan $\mathrm{Cl}^{-}$ sebesar 97,35\% [6]. Pada penelitian tersebut hanya menggunakan sampel air payau yang mengandung kadar klorida (Cl-) awal sebesar $850 \mathrm{mg} / \mathrm{l}$ dengan persentase penurunan $\mathrm{Cl}^{-}$yang terbesar yakni pada debit $100 \mathrm{ml} /$ menit dan waktu sampling 1,5 jam. Kelemahan pada penelitian tersebut adalah hanya berpatokan pada kadar klorida $\left(\mathrm{Cl}^{-}\right)$ sebesar $850 \quad \mathrm{mg} / \mathrm{l} \quad(<1000 \mathrm{mg} / \mathrm{l})$, sedangkan kenyataan yang ada kadar klorida ( $\mathrm{Cl}^{-}$) pada air payau berbagai macam, tergantung jarak sumber air dengan pantai atau laut. penelitian Ruhmawati (2002) menyatakan adanya hubungan antara jarak sumur ke pantai dengan kadar klorida [7]. Kadar klorida umumnya lebih tinggi untuk air yang ke arah pantai [8]. Berdasarkan uraian tersebut maka pada penelitian selanjutnya akan meneliti penurunan salinitas (parameter uji klorida) dengan resin sintetis menggunakan metode pertukaran ion dengan variasi air payau yang dilihat dari kadar klorida awal yang berbeda dan variasi waktu sampling yang digunakan. Penelitian ini diharapkan adanya penurunan kadar klorida dan dapat menentukan perbedaan persentase penurunan kadar klorida pada berbagai variasi kadar klorida awal, pada berbagai variasi waktu sampling dan pada berbagai kadar klorida awal dan waktu sampling.

air payau dengan proses pertukaran ion (Ion Exchange), kemudian mengukur penurunan salinitas (kadar klorida) 
artifisial pada air payau setelah proses tersebut.

Desain/rancang bangun penelitian ini adalah rancangan One Group PretestPosttest Design, pada rancangan ini tidak ada kelompok pembanding (kontrol), tetapi paling tidak sudah dilakukan observasi pertama (pretest) yang memungkinkan menguji perubahanperubahan yang terjadi setelah adanya eksperimen (program)[9]. Rancangan penelitian ini dengan melakukan perlakuan terhadap air payau dengan variasi kadar klorida awal yang berbeda. Kadar klorida air payau yang berbeda didapatkan dari hasil pengenceran air asin menggunakan air tawar. Kemudian air payau tersebut dilewatkan pada media resin sintetis menggunakan proses pertukaran ion (ion exchange) pada debit aliran $100 \mathrm{ml} /$ menit. Penelitian ini juga melakukan pengambilan sampel air setelah proses dengan variasi waktu sampling 1,5 jam, 3 jam, 4,5 jam. Setelah pengambilan sampel, dilakukan pemeriksaan kadar klorida sesudah proses untuk mengetahui persentase penurunan kadar klorida.

Populasi dalam penelitian ini adalah air payau yang memiliki kadar klorida $\left(\mathrm{Cl}^{-}\right)$ diatas standar persyaratan menurut Permenkes RI No.492/MENKES/PER/IV/2010.Sampel yang digunakan dalam penelitian ini adalah sampel air payau yang mengandung kadar klorida $\left(\mathrm{Cl}^{-}\right)$dengan kisaran $\pm 1000 \mathrm{mg} / \mathrm{l}, \pm 2000 \mathrm{mg} / \mathrm{l}, \pm 3000$ $\mathrm{mg} / \mathrm{l}$ dan variasi waktu sampling 1,5 jam, 3 jam, 4,5 dengan jumlah pengulangan adalah sebanyak 3 kali, jadi jumlah sampel untuk dianalisa seluruhnya ada 27 sampel.

Data yang sudah di entry akan dianalisis lebih lanjut secara analitik untuk mengetahui perbandingan persentase penurunan kadar klorida pada masing-masing air payau dengan perbedaan kadar klorida awal dan waktu sampling. Dalam analisis data akan digunakan Uji Two Way Anova, dengan bantuan program komputer SPSS.

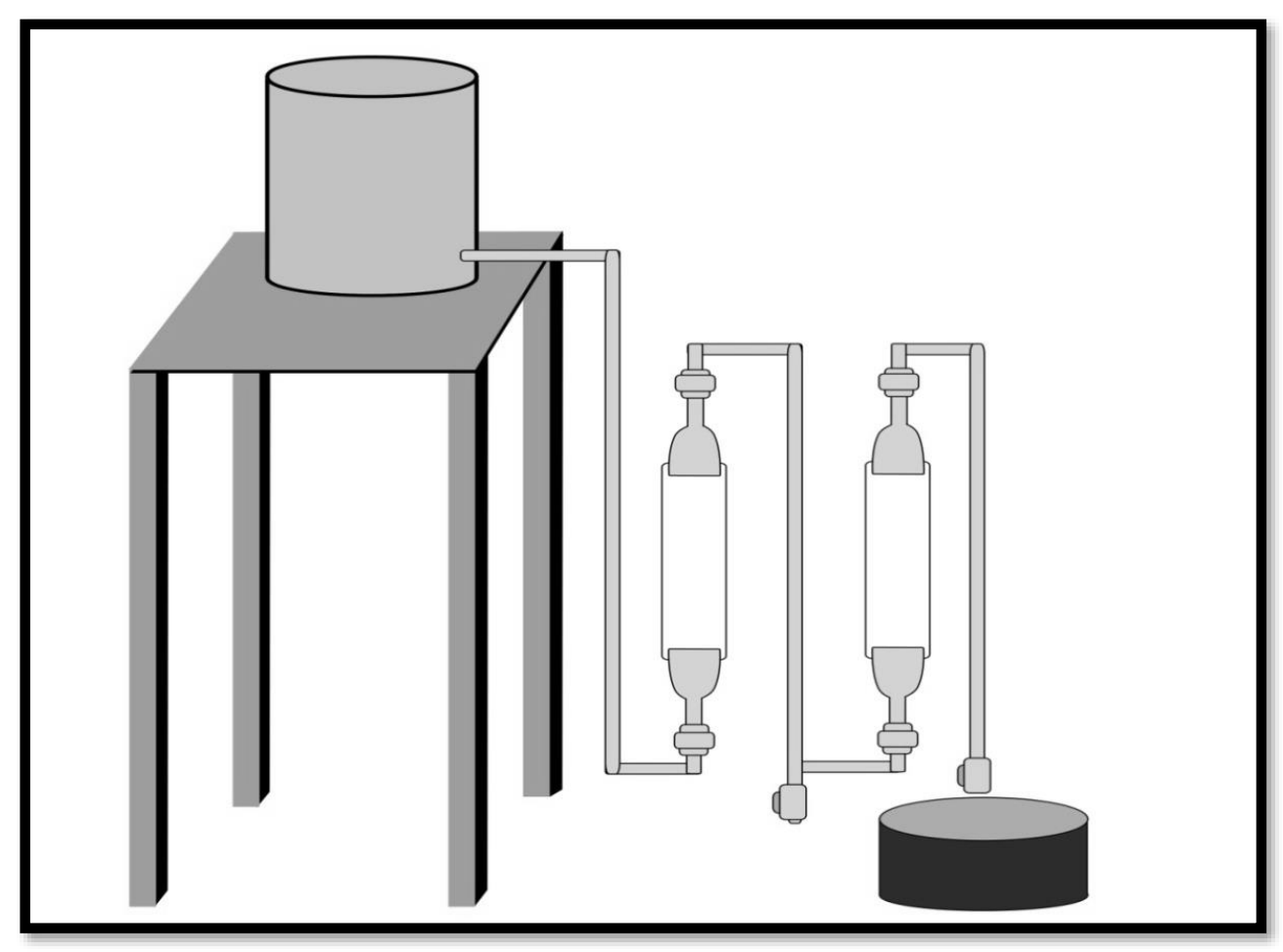

Gambar 1. Rangkaian Alat Proses Pertukaran Ion 


\section{Pemeriksaan Kadar Klorida}

Pemeriksaan kadar klorida sebelum perlakuan dilakukan pada air asin yang belum dilakukan pengenceran. Hasil pemeriksaan didapatkan kadar klorida air asin sebesar 17.300 mg/l. Kemudian dilakukan pengenceran klorida awal \pm 1000 $\mathrm{mg} / \mathrm{l}$ dilakukan pencampuran $1500 \mathrm{ml}$ air asin dan 28000 air tawar sehingga didapatkan kadar klorida awal sebesar 870 mg/l. Pada kadar klorida awal \pm 2000 mg/l dilakukan pencampuran $1500 \mathrm{ml}$ air asin dan 28000 air tawar sehingga didapatkan kadar klorida awal sebesar $870 \mathrm{mg} / \mathrm{l}$. Untuk kadar klorida awal $\pm 3000 \mathrm{mg} / \mathrm{l}$ dilakukan pencampuran $4500 \mathrm{ml}$ air asin dan 28000 air tawar sehingga didapatkan kadar klorida awal sebesar $2501 \mathrm{mg} / \mathrm{l}$. Hasil pemeriksaan kadar klorida sesudah perlakuan dapat dilihat pada tabel berikut :

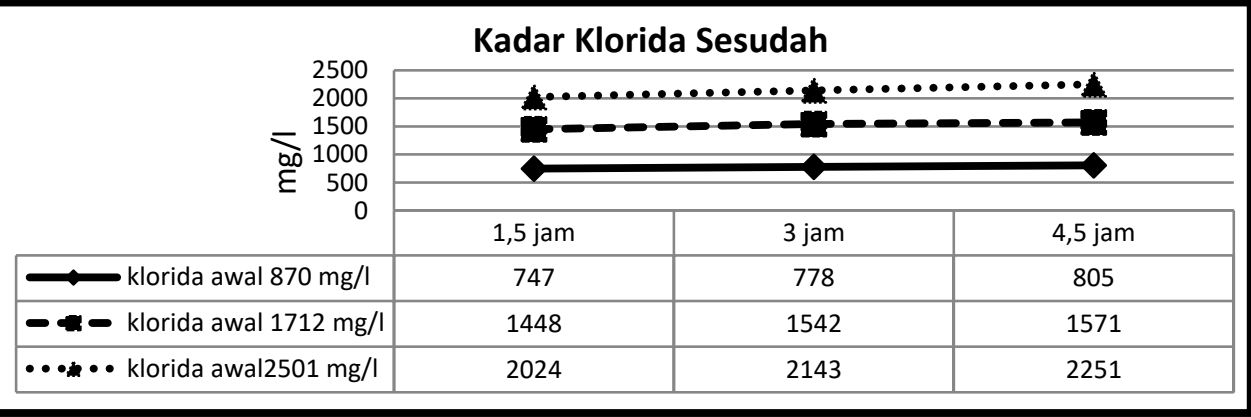

Gambar 1. Grafik Rata-rata Kadar Klorida Sesudah Perlakuan

\section{Penurunan Kadar Klorida}

\section{Selisih penurunan}

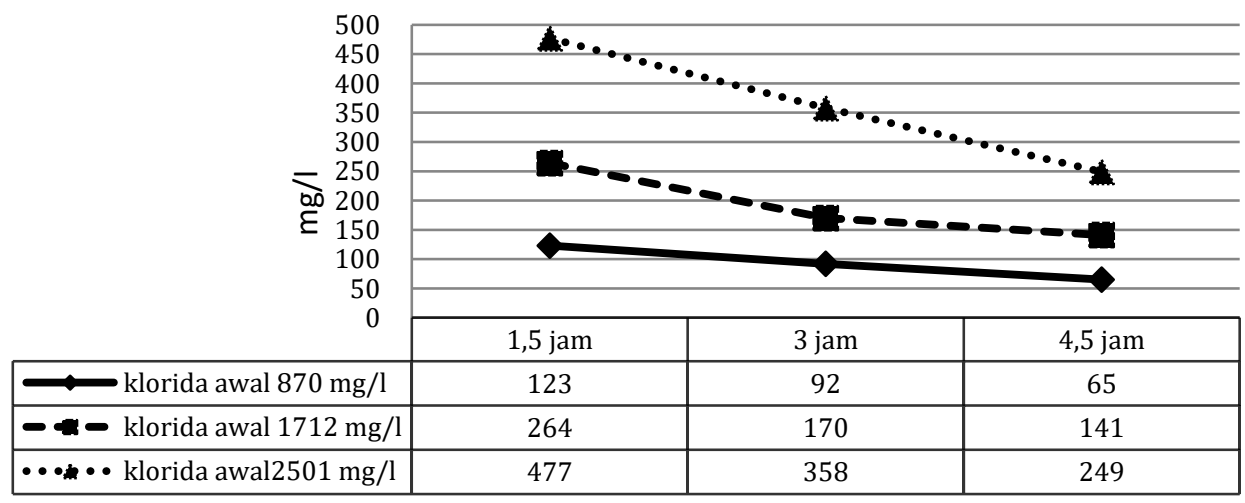

Gambar 2. Grafik Rata-Rata Selisih Penurunan Kadar Klorida Sebelum dan Sesudah Perlakuan 


\section{Persentase Penurunan Kadar Klorida}

Untuk mengetahui persentase penurunan kadar klorida dilakukan perhitungan dengan rumus sebagai berikut :

$\%$ penurunan $=\frac{\mathrm{A}-\mathrm{B}}{\mathrm{A}} \times 100 \%$

Keterangan :

\section{B : Kadar klorida ( $\left.\mathrm{Cl}^{-}\right)$sesudah}

Hasil persentase penurunan kadar klorida pada proses pertukaran ion menggunakan resin sintetis dengan variasi waktu sampling pada kadar klorida $870 \mathrm{mg} / \mathrm{l}$ dapat dilihat sebagai berikut:

A : Kadar klorida $\left(\mathrm{Cl}^{-}\right)$sebelum

\section{Persentase Penurunan}

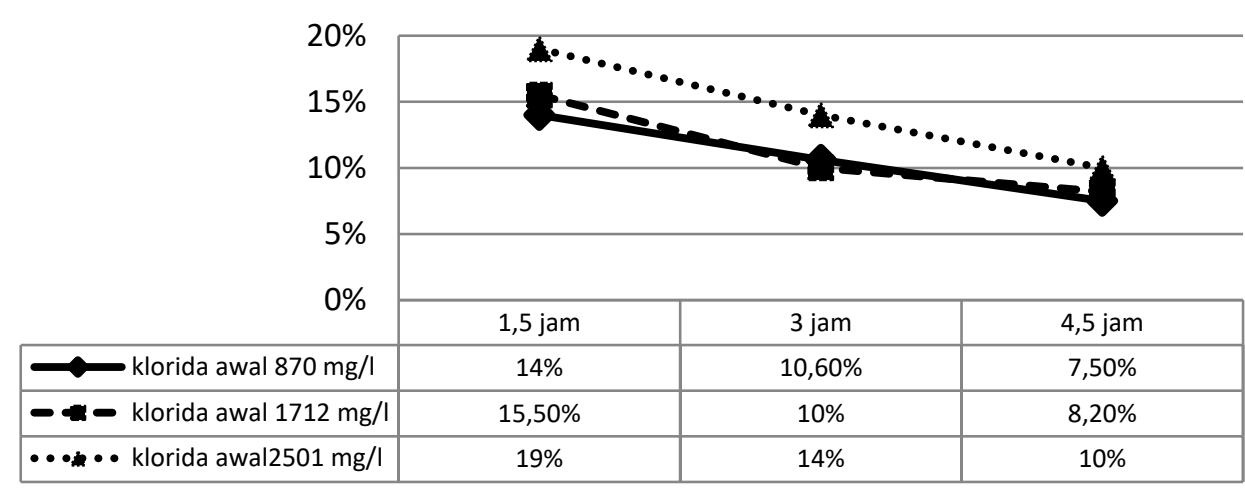

Gambar 3. Grafik Rata-rata Persentase Penurunan Kadar Klorida

\section{Uji Statistik}

Dari hasil uji statitistik diatas antara variabel terikat (persentase penurunan kadar klorida) dengan variabel bebas (kadar klorida awal dan waktu sampling) terdapat perbedaan yang bermakna. Hal ini dapat dilihat pada kolom nilai sig waktu sampling $(0,000)$, nilai sig klorida awal $(0,000)$ dan nilai sig interaksi waktu sampling dan klorida awal $(0,039)$ semua menunjukkan angka $<\alpha$ $(0,05)$.

Untuk mengetahui perlakuan mana yang berbeda pada setiap variasi dilakukan uji LSD (Least Significance Different), dapat diketahi persentase penurunan kadar klorida dengan variasi kadar klorida awal menunjukkan perbedaan pada variasi kadar klorida awal $870 \mathrm{mg} / \mathrm{l}$ dengan $2501 \mathrm{mg} / \mathrm{l}$ dan $1712 \mathrm{mg} / \mathrm{l}$ dan $2501 \mathrm{mg} / \mathrm{l}$, tetapi tidak ada perbedaan persentase penurunan kadar klorida pada variasi $870 \mathrm{mg} / \mathrm{l}$ dengan 1712 mg/l. Diketahui persentase penurunan kadar klorida dengan variasi waktu sampling menunjukkan perbedaan pada variasi 1.5 jam, 3 jam, 4.5 jam.
Kadar klorida merupakan suatu karakteristik air payau yang terjadi karena intrusi air asin ke air tawar dikarenakan adanya degradasi lingkungan [10]. Metode penukaran ion merupakan satu-satunya proses kimia yang dapat menghilangkan klorida dari air. Sedangkan penghilangan secara fisik dapat dilakukan dengan penguapan (destilasi) dan reverse osmosis [11]. Metode pertukaran ion dipengaruhi oleh tinggi media, debit aliran dan ukuran partikel.

Pada hasil pemeriksaan kadar klorida setelah dilakukan proses pertukaran ion menunjukkan hasil yang lebih rendah dari sebelumnya, tetapi semua kadar klorida sesudah masih diatas baku mutu. Penurunan kadar klorida sesuda dilakukan analisis statistik untuk mnegetahui perbedaan pada masing-masing perlakuan. Analisis hasil perbedaan pada masing-masing perlakuan sebagai berikut : 


\section{Persentase Penurunan (Kadar Klorida) pada Berbagai Variasi Kadar Klorida.}

Berdasarkan hasil uji statistik Two Way Anova nilai sig didapat $0.000<\alpha 0,05$ yang menunjukan bahwa terdapat perbedaan yang bermakna dari persentase penurunan kadar klorida artifisial pada berbagai variasi kadar klorida awal, ini diperjelas dengan uji Least Significance Different yang menunjukkan perbedaan persentase penurunan pada 2 variasi kadar klorida awal. Persentase penurunan kadar klorida pada kadar klorida awal $870 \mathrm{mg} / \mathrm{l}$ dan $2501 \mathrm{mg} / \mathrm{l}$, kadar klorida awal 1712 $\mathrm{mg} / \mathrm{l}$ dan $2501 \mathrm{mg} / \mathrm{l}$. Pada kadar klorida awal 870 rata-rata persentase penurunan terbesar $14 \%$, pada kadar klorida awal $1712 \mathrm{mg} / \mathrm{l}$ rata-rata persentase penurunan terbesar $15,5 \%$ dan pada kadar klorida awal 2501 rata-rata persentase penurunan terbesar 19\%. Perbedaan kadar klorida awal ini untuk mengetahui ada perbedaan atau tidak pada penurunan kadar klorida dari masing-masing kadar awal. Karena kenyataan bahwa kadar klorida pada air sumur berbeda-beda, salah satunya dipengaruhi jarak sumur ke pantai [7]. Dari hasil uji statitik persentase penurunan kadar klorida pada variasi $870 \mathrm{mg} / \mathrm{l}$ dan $1712 \mathrm{mg} / \mathrm{l}$, variasi $1712 \mathrm{mg} / \mathrm{l}$ dan 2501 $\mathrm{mg} / \mathrm{l}$ ada perbedaan persentase penurunan kadar klorida. Pada hasil statistik juga diketahui bahwa penurunan kadar klorida pada variasi $870 \mathrm{mg} / \mathrm{l}$ dan kadar klorida awal $1712 \mathrm{mg} / \mathrm{l}$ tidak ada perbedaan. Tetapi dapat diketahui juga bahwa secara nilai absolut semua variasi kadar klorida awal memiliki perbedaan penurunan kadar klorida. Pada hasil penelitian dapat disimpulkan bahwa semakin tinggi kadar klorida maka klorida yang ditukarkan juga semakin banyak dan semakin kecil kadar klorida semakin sedikit pula yang ditukarkan pada media resin. Perbedaan penurunan kadar klorida pada semua variasi juga dipengaruhi dengan level serapan pada proses pertukaran ion.

\footnotetext{
Persentase Penurunan Kadar Klorida Artifisial pada Berbagai Variasi Waktu Sampling.
}

Berdasarkan hasil uji statistik Two Way Anova nilai sig didapat $0.000<\alpha 0,05$ yang menunjukan bahwa terdapat perbedaan yang bermakna dari persentase penurunan kadar klorida artifisial pada berbagai waktu sampling, ini diperjelas dengan uji Least Significance Different yang menunjukkan perbedaan persentase penurunan pada ketiga variasi waktu sampling. Persentase penurunan kadar klorida pada kadar waktu sampling 1,5 jam ada mencapai $20 \%$ dan terendah pada waktu sampling 4,5 jam adalah 7,2 \%. Dari hasil grafik persentase penurunan kadar klorida pada $\mathrm{v}$

ariasi waktu sampling menunjukkan penurunan, semakin lama waktu sampling semakin sedikit persentase penurunan kadar klorida. Penurunan ini dapat terjadi karena resin ion $\mathrm{OH}^{-}$mengalami kejenuhan, Menurut Apriani (2010), semakin lama proses berlangsung maka persentase penyisihan semakin menurun hal ini terlihat dari grafik yang cenderung menurun seiring dengan peningkatan laju aliran dan waktu pengamatan. Lamanya proses waktu sampling sangat berperan penting dalam persentase penyisihan. Semakin lama proses berlangsung dan semakin besar debit aliran maka persentase penyisihan juga makin menurun [6].

\section{Persentase Penurunan Kadar Klorida pada Berbagai Kadar Klorida Awal Dan Waktu Sampling.}

Berdasarkan hasil uji statistik Two Way Anova nilai sig didapat $0.039<\alpha 0,05$ yang menunjukan bahwa terdapat perbedaan yang bermakna dari persentase penurunan kadar klorida artifisial pada berbagai kadar klorida awal dan berbagai waktu sampling. Hal ini diperjelas dengan uji Least Significance Different yang menunjukkan perbedaan persentase penurunan pada interaksi klorida awal dan waktu sampling.

Perbedaan persentase penurunan kadar klorida berdasarkan variasi waktu sampling dan kadar klorida awal berbeda pada kadar klorida awal sebesar $1712 \mathrm{mg} / \mathrm{l}$ dan $2501 \mathrm{mg} / \mathrm{l}$ perbedaan juga dilihat dari waktu sampling (1,5 jam, 3 jam dan 4,5 jam) 
yang semakin lama waktu sampling semakin menurun persentase penurunan kadar klorida. Perbedaan tidak terlihat pada interaksi antara kadar klorida awal 870 $\mathrm{mg} / \mathrm{l}$ dan $2501 \mathrm{mg} / \mathrm{l}$ pada setiap waktu sampling karena persentase penurunan rata-rata yang sama pada interaksi keduanya. Tetapi dilihat dari angka atau nilai absolut semua penurunan kadar klorida berbeda berdasarkan kadar klorida awal dan berdasarkan waktu sampling.

\section{KESIMPULAN DAN SARAN}

Persentase penurunan kadar klorida pada berbagai variasi kadar klorida awal air payau terdapat perbedaan yang bermakna secara statistik ( $p$-value $<\alpha$ $(0,05))$. Rata-rata persentase penurunan kadar klorida pada kadar klorida awal 870 $\mathrm{mg} / \mathrm{l}$ adalah $10.7 \%$ (93 mg/l), pada kadar klorida awal $1712 \mathrm{mg} / \mathrm{l}$ adalah 11,2\% $(191,7 \mathrm{mg} / \mathrm{l})$ dan pada kadar klorida awal $2501 \mathrm{mg} / \mathrm{l}$ adalah 14,3 \% (360 mg/l). Perbedaan persentase penurunan kadar klorida artifisial pada berbagai variasi waktu sampling ada perbedaan yang bermakna secara statistik ( $p$-value $<\alpha$ $(0,05))$. Rata-rata persentase penurunan kadar klorida pada waktu sampling 1,5 jam adalah $16 \% \quad(288 \mathrm{mg} / \mathrm{l})$, pada waktu samplig 3 jam 11,5\% (207 mg/l) dan pada waktu sampling 4,5 jam adalah 8,5\% (151 $\mathrm{mg} / \mathrm{l})$. Perbedaan persentase penurunan kadar klorida berdasarkan kadar klorida awal air payau dan variasi waktu sampling ada perbedaan yang bermakna secara statistik ( $p$-value $<\alpha(0,05))$. Pada kadar klorida awal $870 \mathrm{mg} / \mathrm{l}$ persentase penurunan waktu sampling 1,5 jam sebesar 14\% (123 mg/l) , 3 jam 10,6\% (92 mg/l) dan 4,5 jam 7,5\% (65 mg/l ) . Pada kadar klorida awal $1712 \mathrm{mg} / \mathrm{l}$ persentase penurunan waktu sampling 1,5 jam sebesar 15,5\% (264 mg/l), 3 jam 10\% (170 mg/l) dan 4,5 jam $8,2 \%$ (141 mg/l). Pada kadar klorida awal $2501 \mathrm{mg} / \mathrm{l}$ persentase penurunan waktu sampling 1,5 jam sebesar 19\% (477 mg/l), 3 jam 14\% (358 mg/l) dan 4,5 jam $10 \%$ (249 mg/l).

Pada penelitian ini disaranlan perlu dilakukan penelitian lanjutan dengan variasi waktu kontak agar dapat mengetahui keefektifan resin penukar ion dalam menurunkan kadar klorida. Perlu dilakukan penelitian lanjutan dengan menambah parameter pemeriksaan yakni kadar natrium, karena natrium merupakan ikatan ion klorida yang membentuk garam dan dapat menyebabkan rasa asin pada air. Pengolahan air payau yang memiliki kadar klorida tinggi dapat melakukan gabungan proses atau metode lain yang bisa menurunkan kadar garam seperti reverse osmosis atau sistem desalinasi lainnya.

\section{KEPUSTAKAAN}

1. Dewi LK, Azfah RA, Soedjono ES, 2014. Rancang bangun alat pemurni air payau sederhana dengan membran reverse osmosis untuk memenuhi kebutuhan air minum masyarakat miskin daerah pesisir. Jurnal Teknik Lingkungan, Fakultas Teknik Sipil dan Perencanaan, ITS Surabaya .

2. Kurniawan A, Rahadi B, Susnawati LD, 2014. Studi pengaruh zeolit alam termodifikasi HDTMA terhadap penurunan salinitas air payau. Jurnal Sumber Aaya Alam dan Lingkungan Universitas Brawijaya .

3. Said NI, 2003. Teknologi Reverse Osmosis.

4. Khairunnisa U, Elystia S, Zultiniar, 2015. Efisiensi penurunan kadar natrium $\left(\mathrm{Na}^{+}\right)$dan klorida $(\mathrm{Cl})$ pada air laut menggunakan tanah lempung dengan metode penukar ion. Jurnal Teknik Lingkungan Universitas Riau Vol 2 No.2

5. SA Kardjono, 2007. Proses pertukaran ion dalam pengelolaan air. Jurnal Publikasi Ilmiah Pusdiklat Migas .

6. Apriani RS, Wesen P, 2010. Penurunan salinitas air payau dengan menggunakan resin penukar ion. Jurnal teknik Lingkungan Universitas Pembangunan Nasional.

7. Ruhmawati $T, 2002$. Hubungan Jarak Sumur Gali Ke Pantai Dengan Kadar Klorida Air Sumur Di RW 07 Kelurahan Bandarharjo Semarang. Skripsi Universitas Dipenogoro Semarang.

8. Irma UA, Birawida AB, Manyullei S, 2014. Studi sanitasi dasar pada penderita diare dan tifoid di pulau 
Barrang caddi kota Makassar. Jurnal Kesehatan Lingkungan Fak.Kesehatan Masyarakat Universitas Hasanuddin .

9. Notoatmojo S, 2012. Metodologi Penelitian Kesehatan, Rineka Cipta, Jakarta.

10. Soedjono E, 2002. Diktat Kuliah Pengelolaan Penyediaan Air Bersih.

Budiono, Sumardiono S, 2013. Teknik Pengolahan Air, Graha Ilmu, Yogyakarta 
